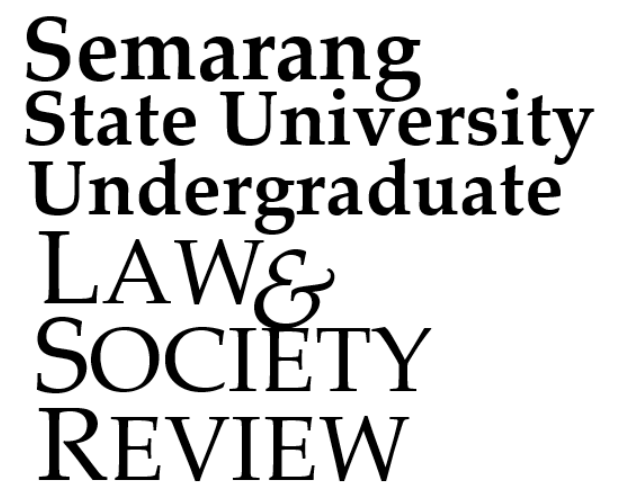

VOLUME 1 ISSUE 1, JANUARY 2021
ISSN (Print): 2807-8225 ISSN (Online): XXXX-XXXX

\author{
History of Article \\ Submitted: November 2020 \\ Revised: December 2020 \\ Accepted: January 2021
}

How to cite:

Permata, V. H. (2021). Online Prostitution Amidst the Rapid Technological Advances: Legal and Social Aspects. Semarang State University Undergraduate Law and Society Review, 1(1), 19-34. https://doi.org/10.15294/lsr.v1i1.49837

(C) 2021 Authors. This work is licensed under a AttributionNonCommercial-ShareAlike 4.0 International (CC BY-NC-SA 4.0). All writings published in this journal are personal views of the authors and do not represent the views of this journal and the author's affiliated institutions.

\title{
Online Prostitution Amidst the Rapid Technological Advances: Legal and Social Aspects
}

\author{
Verania Hedi PERMATA® \\ University of Pamulang \\ Jl. Surya Kencana No.1, Pamulang Bar., Kec. Pamulang, Kota Tangerang \\ Selatan, Banten 15417, INDONESIA \\ 凶veraaniaprmtr@gmail.com
}

\begin{abstract}
Today almost everyone is using the internet, because from the internet we can get all the information easily and quickly. but not everyone knows the dangers of using the internet. because it is not uncommon also someone to commit crimes through the internet (cybercrime). Cybercrime is the negative side of technological advances for all areas of modern life that exist today. one of the crimes that can occur through internet access is online prostitution. The online prostitution activity is a negative impact of social media abuse. One effort that can be
\end{abstract}


used to cope with online prostitution activity that occurs is with the approach of criminal law policy through criminal sanctions as a concrete form of criminal responsibility to perpetrators of online prostitution. The disclosure of online prostitution cases proves that social media is a powerful tool for the promotion of prostitution. Such prostitution activity is the effect of unlimited use of online social media. In the absence of a national regulation that regulates this matter, online prostitution users will feel secure and liberal in purchasing services for their own satisfaction, while in fact it is contrary to legal norms in society.

KEYWORDS. Online Prostitution; Cybercrime; Legal Aspect; Social Analysis

\section{INTRODUCTION}

In everyday life, the use of the Internet has become the need of everyone from children to the elderly, the internet to various business or social activities. The development of Science and Technology, especially in information and communication technology, just bring a big factor to life. So, Law No. 11 of 2008 on Information and Electronic Transactions (hereinafter as ITE Law) as it is very necessary for the state of Indonesia, because it is now a lot of people who have been using and utilizing information technology widely. Law No. 11 of 2008 on ITE has many benefits that can be done, can be used based on information, ensuring certainty for people who make electronic transactions (Juita, 2016).

The Government views the Information and Transaction Act Electronic is necessary for the state of Indonesia, as it is currently Indonesia is one of the countries that have been using and utilizing technology information widely and efficiently. In accordance with the development process in the era of globalization, as well as the increasing quality of technology, Indonesian society has now undergone many changes because of the advance development of Science and Technology. The current 
thinking of society has also been influenced by various things. Electronic media that has grown more rapidly has a great influence for the community, one of them because of something new then it can have an impact that can affect the behaviour of the community.

The impacts can be either positive or negative impacts. Positive impacts make it easy for the community to complete its activities, while the negative impacts can be the decline of public morals, with the infiltration of foreign cultures through online media, the rampant pornography that causes sexual harassment, online gambling, cybercrime, and more recently this rampant is the practice of online prostitution business through social networking or other sites (Hartanto, 2015; Puspitosari, 2010).

In the further context, Darmawan emphasized that problem is one of the problems that is always interesting and always demands serious attention to the community from time to time. Moreover, the general and several observations and research of various parties, there is a tendency of form and type of crime, both in quality and quantity. ITAC (Information Technology Association of Canada) said that "cybercrime is real and growing threat to economic and social development around the world" (Arief, 2010). One of the most controversial cases in cybercrime is online prostitution.

Prostitution is a prostitute or sex worker or commercial sex worker or sex retailer. Meanwhile, according to the term, prostitution is a job that is done by surrendering or selling sexual services by getting rewards from people who use sexual services in the form of wages. Actually, prostitution has existed long before the modern times come and touch the community, it can be said that prostitution including the disease of society that cannot be removed or removed from human life. Too many factors support for the occurrence of prostitution, consciously or not a teenager can be affected by the negative globalization. because of the increasingly modern era of internet connection is easier and easier to access and we can at any time access the internet easily only with mobile phones, but it turns out when technology is growing in situ also the community is also growing, the use of mobile phones can be misused by spreading photos or video which can 
make teenagers mature and try to channel them the wrong way (Ardila, 2016; Hughes, 2004).

Prostitution is not only about the moral quality of the perpetrators. Prostitution will cause sexually transmitted diseases like HIV/AIDS. a woman infected with this disease can give birth to children with physical disabilities, which may cause problems in the quality of future generations. Especially about the spread of HIV/AIDS (Koentjoro, 1996).

The origin of prostitution in Indonesia begins from the period of the Javanese kingdom where the trafficking of women at the time was a reestablishment of the feudal system of government. At that time the concept of power of a king in describing as a supreme and noble power. The king is regarded as someone who is powerful because it has a lot of possessions. Prostitution also evolves with the times-the era of Information and Communication Technology (ICT) can also affect the prostitution itself.

Online prostitution is an activity of prostitution or an activity that makes someone as an object to be traded through electronic or online media or often called cyberspace, the media used such as, whatsapp, facebook, instagram, and other social media. Online prostitution is done with the media because it is easier and safer than the official raid on prostitution that is done in the conventional way. According to Bonger he says prostitution is a social phenomenon in which women sell themselves into sexual acts as a search for life. In this definition clearly the existence of self-sales events as "profession" or daily livelihood, by way of sexual relationships (Humairah, 2016; Karo, Pasaribu, \& Sulimin, 2018).

The Indonesian Commission for Child Protection (KPAI) revealed that there are six reasons why online prostitution, prostitution is very popular among the lower, upper, artist, through social media. Firstly, because of the pimps' exploitation factor, not a few women and even children trapped, tricked, seduced unknowingly were employed as commercial sex workers, second factor is the existence of economic needs that make them think instantly that by working as a prostitute their economy quickly improved and earn a lot of money. third, forced coercion, 
enslaved by a person or group of sexual workers, four influences of a neighbourhood or a peer, five hedonic lifestyle influences and the sixth is a frustrating factor (Fajarwati, 2017).

First online prostitution in Indonesia was revealed on May 3, 2003. Reskrimsus cybercrime unit of Metro Jaya Police managed to catch the pimps online, the culprit is a husband and wife. This online prostitution is by offering women through a website address. The owner of this account display photos of the woman in a sexy fashion then the enthusiasts simply by calling the phone number (mobile phone) pimps, then pimps will deliver orders to the hotel room or to the apartment in accordance with the wishes of each customer (Yanto, 2016).

The last word of this online prostitution term can already describe the place where this activity is performed. Online is a term people use to state something related to the internet or cyberspace. Thus, online prostitution is an activity that offers sexual services through cyberspace or the internet. This online prostitution can be defined in general terms is the practice of prostitution or prostitution by using the internet or online media as a means of transactions for those Commercial Sex Women (PSK) and for those who want to use his services. Although the notion of online prostitution is a prostitution transaction that uses the internet media as a means of liaison between the PSK with someone who wants to use his services. So, the internet only for the means of support or liaison only. Unlike in general, CSW transactions are waiting for customers on the sidewalk. All these definitions have their own problems because they are defined from different societies that basically also have different social and moral standards about prostitution or prostitution itself.

The type of research that is done is descriptive qualitative research. The purpose of the research is the research of qualitative data. Data presented in verbal form, which emphasizes on contextual issues and is not tied to the calculation of numbers or measures that are empirical. Data is generally in the form of narration, drawings. Data can be obtained through, observation, interview, recording, and so forth. This study is a 
type of research that describes the Use of social media as an Online Prostitution Facility. The method of research on the reformulation of criminal responsibility on the perpetrators of online prostitution is normative legal research, i.e., research that focuses only on secondary data only. Research Specification: from the title and the existing problems of this research, this research is included in descriptive-analytical research, which describes the laws and regulations that apply as positive law associated with legal theories and practice implementation of positive law in society. Thus, this study can provide an overview of the reorientation of criminal law policy on criminal liability to perpetrators of online prostitution. Types and Data Sources: In this study used secondary data sources in the form of primary, secondary, and tertiary legal materials, including Indonesian Penal Code (KUHP), Law No 44 of 2008 concerning Pornography, and Law No 11 of 2008 on Information and Electronic Transactions.

The data that have been collected in the next analysis qualitatively means that data based on the description of sentences or data are not analyzed by using statistics or mathematics or the like, that is what is stated by the respondent in writing or oral and real behavior that is in carefully and studied as something intact. And by using the deductive method by analyzing from the problems that are general to things that are specific of course by using analysis based on the existing literature.

\section{ONLINE PROSTITION AND ITS LEGAL ASPECT}

Good Law according to Lawrence Friedman must always contain three elements of the legal system part of the legal structure, legal substance, and legal culture. Therefore, everything that will be carried out in a national legal system or country should be adjusted to the conditions and interests of a country concerned. The passing of the 1945 Constitution as the constitution of the state of Indonesia has an impact on all the rules of law applicable in Indonesia must always be sourced from the Constitution, especially in the preamble of the 1945 Constitution which is a spiritual 
principle in which there is a basic philosophy of the state namely Pancasila (Philosofische Groundslag) (Amalia, 2016).

According to Jimly Asshiddiqie, the idea of a legal state, in addition to the concept of rechtstaat and the rule of law, is also related to the concept of nomocracy derived from the words of nomos and cratos. The decisive factor in the exercise of power is the norm or law, so the term nomocracy is closely related to the idea of the rule of law or the principle of law as supreme power.

\section{A. An overview of prostitution}

Prostitution in Indonesia has been regarded as a crime of "moral decency" and unlawful acts. In practice, prostitution is widespread, tolerated, and regulated. Prostitution is the most visible practice of prostitution, often embodied in Indonesian prostitution complexes also known as "lokalisasi (in Bahasa)" and can be found also throughout the country. The brothel is managed under local government regulations. UNICEF estimates that 30 percent of female prostitutes in Indonesia are women under 18 or children. (Melinda, 2017; Yudha, Utamidewi, \& Adirasa, 2018).

Prostitution is a form of sexual crime committed with and / or nonviolence. This crime can be a violent act when prostitution is committed with trafficking and coercion. Cases of sexual trafficking are common in underage girls, which can indicate that the reality of women's human rights to enjoy peace and happiness has often been violated from an early age (underage). The right to live in dignity and free from the dangers that threaten itself has been reduced by crime because there are still many children brought ages which women cannot enjoy the right to live comfortably and be free from danger (Wahid \& Irfan, 2001). 


\section{B. Criminal policy in the field of cybercrime}

The United Nations VIII/1990 Congress on "computer related crimes" made several attempts to overcome the cybercrime, namely:

a. urges members of the state to intensify computer mitigation efforts more effectively by using the following steps:

1) developing prevention of computer security

2) modernize the criminal law

3) sensitizing citizens against the dangers of Internet-related crimes or computers.

Prevention and prevention of crime can not only be overcome by the enforcement of criminal law alone but must be done with other efforts that are outside the penal law (non-penal). Such non-penal efforts through political, economic, and socio-cultural policies. In addition, non-penalty efforts can also be pursued by nourishing the community through social policy and exploring the potentials that exist within the community itself.

\section{B. criminal law enforcement online prostitution}

According to Soerdjono Soekanto, Law enforcement is an activity that harmonizes the relationship of values that have been described in the existing rules and an attitude as a series of elaboration of the final value of the value, to create, maintain and maintain peace of life in life (Soekanto, 1982).

Laws that are created by the holder of power authority as a system of supervision of human behaviour. As this norm is binding for everyone to submit and follow all the rules contained therein. The existence of cyber law, in this context also applies to the netter who often interact in cyber space. In order for this law to function it must meet some legal requirements of law (Ali, 2010) as follows: 
1) The rule of law applicable juridically, that is, if its determination is based on higher or higher rules established on the basis established by law;

2) The rule of law that applies sociologically, ie if the rule can be effective. That is, the rule can be enforced by the authorities even though it can not be accepted by the citizens (power theory) or the rule can apply because of the existence of the recognition of the wider community; and

3) Law rules that apply philosophically, that is in accordance with the ideals of law which has the highest positive value.

The act of buying and selling by the act of disseminating and / or broadcasting, with the intent of the consequence of the deed that the object being sold to be widespread in many places and known by the people. a buyer is an agreement between two parties called seller and buyer, the seller is obliged to deliver an object or goods to another party called a buyer, and the buyer is obliged to pay to the seller at a specified price already agreed (Chazawi, 2009).

In Indonesia it is clear there is no law that regulates prostitution or prostitution in particular, but here can be seen from the meaning of pimping juridically that a man or woman who perform or provide facilities and make himself an obscene intermediary or sexuality already as a habit or livelihood, they also took advantage of the prostitution business. The acts committed by pimps are acts that violate the provisions set forth in the Criminal Law. The article that can be imposed on a pimp is Article 296 of the Criminal Code, in Article 296 of the Criminal Code which is about the person who provides the place or the person to commit obscene (Gayatri \& Novy, 2019).

This sexual crime does not only occur in adult women, but also affects minors. Girls serve as the object of a commercial or animalistic lust of a certain man and group operating a sexual business in order to achieve rapid and multiply economic benefits in the child's trade. With internet media they get some benefits, for example, their average customer is educated. In addition, if prospective customers are not pleased, sex 
workers do not need to spend time or spend money to come to their prospective customers. Meanwhile, for customers is also quite beneficial considering the sex workers have detailed their data. Connecting with sex workers who offer themselves through online media is also considered more convenient and easy. What's more, most of the sex workers came from the upper middle class.

Crime countermeasures are essentially integral to the protection of society. Therefore it can be said that the ultimate goal or the main purpose of criminal politics is to protect the society to prosper in the life of society (Arief, 2001). Criminal law enforcement is part of crime prevention policy (criminal politics), with the ultimate goal is the protection of society to achieve prosperity in the environment. Thus the enforcement of criminal law in the form of improvement of legislation with the implementation and implementation of criminal law and increase the participation of the community to participate in tackling existing criminal acts.

\section{ONLINE PROSTITION AND ITS SOCIAL ASPECT}

\section{A. Factors of Prostitution Online}

The number of prostitution activities in Indonesia shows that prostitution has become a scourge for the morale of the people in Indonesia. the government is very difficult in eliminating the practice of prostitution. Due to the difficulty of arranging it, the government finally made localization for prostitution in Kramak Tunggak, Jakarta and also developed outside Jakarta, such as in Surabaya. although the government legalized localization in Jakarta and Surabaya but still rejected by many local people because of the existence of localization can certainly damage the morale of the community, especially the young generation of this country. Several factors cause prostitution through online media. 
First, the weakness of the level of faith. Basically, faith is the foundation of a person in living this life. Each religion has its own rules of command and prohibition. No religion permits prostitution. With a good faith based, hopefully someone will be strong living this life.

Second, poverty. Poverty forces many people to sell their morality. Basically, the main cause of prostitution is the deterioration of Indonesia's economic condition. Many people are out of work. The job opportunities are not worth the number of people looking for work. This situation makes people work hard to find jobs to other countries. On the other hand, seen in the context of families, women are seen as "alternative workers" to ensure the survival of one family.

Third, the desire quickly get rich (materialistic). The desire to have material and a higher standard of living. This activity has entered the educational environment. Students junior high, high school, many students who are in the world because of the desire to be able to immediately meet the needs of a luxurious lifestyle.

Fourth, cultural factors. Culture of cyberporn on the internet by posting pornographic photos without shame and openly offering himself with a certain rate. Online prostitution sites become a business medium that provides greater benefits than the form of prostitution in general. Fifth, the weakness of law enforcement in overseeing the circulation of cyberporn. Online prostitution and pornographic activities are considered "latent danger" which is always present and evolved even though it continues to be eradicated (Sonbai, 2019; Pratama, 2019).

For that, prosecuted the firmness of law enforcement officers in providing "shock therapy" on the loading of porn sites. Of the many factors a person plunges in the world of prostitution, the authors argue economic factors are often used as the main reason. Whatever the factor and effect of prostitution, certainly the job as the culprit will not get a respectable place in society let alone in God's side (Arief, 2001). 


\section{B. Criminal offense for pornographic service providers}

Article 30 jo article 4 paragraph (1) shall be as follows: Any person providing pornographic services may be subject to imprisonment of a minimum 6 (six) months and a maximum of 6 (six) years and / or a minimum fine of $\operatorname{Rp} 25,000.000 .00$ and at most Rp.3.000.000.000,00.

In Article 4 paragraph (2) any person is prohibited from providing pornographic services that explicitly prescribe genitalia, presenting nudity or impressive display of nudity, and offering sexuality services either directly or indirectly. If pornographic services are used by others, such as for a pornographic exhibition, the person has committed a pornography as a sole author and violates article 32 for committing a criminal act of showing pornography (Andriyani, Widihastuti, \& Nugroho, 2021).

\section{CONCLUSION}

Law enforcement on prostitution crime online by Pekanbaru Town Police Department should be done in a more intensive and thorough way, because online prostitution is very fast, and the spread of the activities or transactions are done through electronic media so that the police also difficult in terms of looking for goods evidence and investigation is also difficult to do. 2. In the hope to the public to be more concerned about online prostitution activities so that it can facilitate the Pekanbaru City Police Department in tackling it. And also, the government's pause is expected to provide more tools and technologies to facilitate the process of investigation in the case of prostitution online crime. 3 . It is expected that the Government and Resort Police of Pekanbaru City will be more active in conducting prostitution education activities online so that the students are aware of the impact and the government is also expected to provide 
more adequate tools and technology to facilitate the investigation process in the case of prostitution crime online.

Social media or internet users need to be more sensitive to awareness not only from the online media, but also need awareness from us as users to report when there is inappropriate dissemination of information and should be eliminated. urged to all parents to always limit their son and daughter in using the computer let alone the use of the Internet without supervised smart phone or android so as not to exceed the limits with the use of a negative direction such as opening an online prostitution site or pornographic content. for social media users to utilize social media to seek information and science that is positive for its users. Should all social media verify which information or account is correct and reliable so that social media can be used with positive and appropriate things.

\section{REFERENCES}

Ali, Z. (2010). Filsafat Hukum. Jakarta: Sinar Grafika.

Amalia, M. (2018). Analisis terhadap tindak pidana prostitusi dihubungkan dengan etika moral serta upaya penanggulangan di kawasan Cisarua Kampung Arab. Jurnal Hukum Mimbar Justitia, 2(2), 861-880.

Andriyani, L., Widihastuti, A., \& Nugroho, A. (2021). Challenges and support to access and retention in HIV care continuum of female sex workers living with HIV in Indonesia: A mixed-method study. Unnes Journal of Public Health, 10(2).

Ardila, J. (2016). Upaya Penanggulangan Prostitusi (Studi di Polresta Bandar Lampung). Thesis, Universitas Lampung

Arief, B. N. (2001). Masalah Penegakan Hukum dan Kebijakan Penanggulangan Kejahatan, Bandung: Mandar Maju.

Arief, B. N. (2010). Masalah Penegakan Hukum dan Kebijakan Hukum Pidana dalam Penanggulangan Kejahatan. Jakarta: Kencana. 
Arsanti, M. (2017). Penggunaan Media Sosial Sebagai Sarana Prostitusi Online. E-Journal Ilmu Komunikasi, 5(3).

Chazawi, A. (2009). Tindak Pidana Pornografi. Surabaya: Lentera.

Fajarwati, S. R., Rahayuningsih, T., \& Murni, A. (2017). Dinamika Psikologis Mucikari Remaja pada Prostitusi Online. Psychopolytan: Jurnal Psikologi, 1(1), 17-22.

Gayatri, P. A., \& Novy, I. W. (2019). Pertanggungjawaban Pidana Para Pihak yang Terkait dalam Prostitusi Online. Kertha Wicara: Journal Ilmu Hukum, 8(3), 1-8.

Hartanto, D. A. (2017). Penganggulangan Prostitusi Online Perspektif Pembaharuan Hukum Pidana di Indonesia dan Hukum Pidana Islam. Thesis, Universitas Muara Kudus

Hughes, D. M. (2004). Prostitution online. Journal of Trauma Practice, 2(3-4), 115-131.

Humairah, V. (2016). Penegakan Hukum Tindak Pidana Prostitusi Secara Online di Wilayah Hukum Polisi Resor Kota Pekanbaru. Jurnal Online Mahasiswa Fakultas Hukum, 3(2), 1-12.

Juita, S. R., Triwati, A., \& Abib, A. S. (2017). Reformulasi Pertanggungjawaban Pidana Pada Pelaku Prostitusi Online: Suatu Kajian Normatif. Jurnal Dinamika Sosial Budaya, 18(1), 146-158.

Karo, R. K., Pasaribu, D., \& Sulimin, E. (2018). Upaya Preventif Dan Represif Terhadap Prostitusi Online Berdasarkan Peraturan Perundang-Udangan Yang Berlaku Di Indonesia. Lex Journal: Kajian Hukum \& Keadilan, 2(2).

Koentjoro, K. (1996). Prostitusi di Indonesia: Sebuah Analisis Kasus di Jawa. Buletin Psikologi, 4(2).

Pratama, Y. N. (2019). Women Exploitation in Prostitution Business. Lex Scientia Law Review, 3(1), 103-110.

Puspitosari, H. (2010). Upaya Penanggulangan Prostitusi Online Internet Berdasarkan Undang-Undang Nomor 11 Tahun 2008 tentang Informasi dan Transaksi Elektronik (ITE). Surakarta: Jurnal Komunikasi Massa, 3(1). 
Soekanto, S. (1982). Pengantar Ilmu Hukum. Jakarta: Gramedia.

Sonbai, A. I. K. (2019). Kebijakan Formulasi Pertanggungjawaban Pidana Pengguna Jasa Prostitusi Melalui Media Online. Jurnal Hukum Kenotariatan Acta Comitas 4 (2), 281.

Wahid, A., \& Irfan, M. (2001). Perlindungan Terhadap Korban Kekerasan Seksual Advokasi atas Hak Asasi Perempuan. Bandung: Refika Aditama.

Yanto, O. (2016). Prostitusi Online sebagai Kejahatan Kemanusiaan terhadap Anak: Telaah Hukum Islam dan Hukum Positif. AHKAM: Jurnal Ilmu Syariah, 16(2), 187-196.

Yudha, T., Utamidewi, W., \& Adiarsa, S. R. (2018). Prostitusi Online Dan Eksistensi Kekuasaan Pemerintah. Jurnal Sosial Soedirman, 2(1).

\section{Conflicting Interest Statement}

All authors declared that there is no potential conflict of interest on publishing this article.

\section{Funding}

None

\section{Publishing Ethical and Originality Statement}

All authors declared that this work is original and has never been published in any form and in any media, nor is it under consideration for publication in any journal, and all sources cited in this work refer to the basic standards of scientific citation. 
One of the main cyber-risks is to think they don't exist. The other is to try to treat all potential risks. Fix the basics, protect first what matters for your business and be ready to react properly to pertinent threats. Think data, but also business services integrity, awareness, customer experience, compliance, and reputation.

Stephane Nappo 